\title{
Suriye’deki Kürt Siyasi Partiler Üzerine Genel Bir Değerlendirme
}

\author{
Bekir Halhalli*
}

Received: Dec 13, 2016 Reviewed: Dec 31, 2016 Accepted: Jan 25, 2017

\section{$\ddot{O} \mathbf{z}$}

Kürt halkının üzerinde yaşamış olduğu gerilimli coğrafya farklı Ortadoğu modern-ulus devletlerinde pek çok kurum ve siyasi parti tarafından legal ve illegal oluşumlarla günümüze kadar önemini artırmıştır. Özellikle Arap Ayaklanmaları esnasında ve sonrasında bölgedeki değişim rüzgârları mevcut otoriter rejimleri birer birer devirirken onların baskı altında tuttuğu grupların siyaset arenasında yerlerini almalarını sağlamıştır. Suriye ayaklanmasıyla toplum içinde çeşitli şekillerde bölünmeler yaşanmasına rağmen Suriye Kürtleri kaderlerini tayin etme hakkını savunmak için önemli tarihi firsat yakalamıştır. Bir başka deyişle, Suriye'de yıllardır süren Baas rejiminin baskı altında tuttuğu ve manipüle ettiği Kürtler, artık göreceli olarak kendi adlarına hareket etmeye başladılar. Bu durum bölgede değişimi savunan pek çok yerel , bölgesel ve uluslararası aktörün stratejik politikalarını derinden etkilemektedir . Bu çalışma, Suriye'deki Kürt siyasi partilerin genel bir bakışını sunmaktaleplerini benzerliklerini, farklılıklarını ve örgüt tarzlarını saptamak-Irak , İran ve Türkiyedeki Kürt siyasi hareketleriyle ilişkilerini irdelemek gibi konulara odaklanmaktadır. Bunun yanı sıra, çalışmada Suriye'deki Kürt siyasi partilerin yol haritaları açıklanarak bölgesel ve uluslararası ilişkileri de incelenecektir.

Anahtar Kelimeler: Suriyeli Kürtler, Rojava, Kürt Siyasi Partileri, Suriye

\section{A General Assessment of the Syrian Kurdish Political Parties}

\begin{abstract}
The high-profile geography where the Kurdish people lived on has increased its importance created by many organizations and political parties in different Middle East of the modern nation-states with legal and illegal formations until today. Especially during the Arab Revolts and afterwards whilst the winds of change in the region brought down the existing authoritarian regimes one by one, it helped them to take their place in the political arena of the groups that they hold them under pressure.

Although being experienced the cleavages in various ways in the community due to Syrian uprising the Syrian Kurds caught the important historic opportunity to defend their rights to self-determination. In other words, the Kurds that were oppressed and manipulated by the Ba'ath regime ruled in Syria for years, they began anymore to act on their behalf relatively. This situation is being affected the strategic policy of the most local, regional and international actors advocating change in the region deeply.

This study / article focuses on issues such as to present an overview of Kurdish political parties in Syria, to determine the demands, similarities, differences and the organization style, to analyse the Iraq's relations with Iran and the Kurdish political movement in Turkey. Even Syrian Kurdish politics is complex the article deals with leading the Kurdish parties in Syria, examines functions/structures of political parties in the historical context of Syria by analysing developments in the Kurdish political sphere at the regional level.
\end{abstract}

\footnotetext{
* Sakarya Üniversitesi Uluslararası İlişkiler Bölümü Doktora Adayı, bekir.halhalli@ogr.sakarya.edu.tr
} 
In addition to this, by explaining the road maps of Kurdish political parties in Syria and regional and international relations will also be examined.

Keywords: Syrian Kurds, Rojava, Kurdish Political Parties, Kurdish Movement

\section{Recommended citation:}

Halhalli, B. (2017). Suriye'deki Kürt Siyasi Partiler Üzerine Genel Bir Değerlendirme. International Journal of Kurdish Studies 3 (1), 42 - 60 DOI: 10.21600/ijoks.288968

\section{Giriş}

Osmanlı İmparatorluğu'nun dağılmasından sonra imzalanan Sykes-Picot Antlaşması (1916) sonucunda Kürtler, Kürdistan bölgesinin en zayıf halkası haline gelmiştir. Çok etnilli, dilli, dinli imparatorluk yönetimleri üzerine inşa edilen tekçi anlayışa dayanan ulus-devlet düzeninden en çok zararı Kürtler ve Kürdistan görmüştür. Batı kaynaklı 'ulus-devlet' modeli, Kürtleri sisteme dâhil etmek yerine onları ya 'asimile' edilmesi gereken bir unsur, ya da ileride kolaylıkla çözülebilecek 'azınlık' olarak görmüştür. Kürt halkının üzerinde yaşamış olduğu gerilimli coğrafya yönetilir kılınabilmek için adeta ekonomik, coğrafi, çıkar ilişkileri ve örtülü hesaplaşmalar gibi amaçların ışığında cetvel ile çizilmiş; ulusal nüfus realitesi, aşiret bağları ve tarihsel-kültürel bağlantılar yok sayılmıştır. Dolayısıyla, her dört komşu ülkede de Türkiye, İran, Irak ve Suriye, Kürt milliyetçiliğine dayalı sosyal, siyasi ve askeri yapılanmalar ortaya çıkmıştır. Diğer bir ifadeyle, askeri, siyasi ve ekonomik otoritenin egemenliği altında her bir ülkede Kürt milliyetçi hareketi farklı şekillerde gelişmiştir (Tejel, 2015: 180).

Suriye Kürdistanı'nın Osmanlı Kürdistanı'ndan ayrılmasıyla I. Dünya Savaşı'ndan sonra Türkiye ile Fransa arasında 1921 yılında imzalanan Ankara Antlaşmasıyla gerçekleşmiştir. 1921 yılından günümüze, yani 2012 Rojava (Kürtçe'de Rojava "Batı" anlamına gelir) Devrimine kadar savaş ve askeri darbelerin hüküm sürdüğü farklı sosyokültürel ve farklı iktidarların geldiği Suriye devletinde neredeyse değişmeyen tek şey Kürtlere uygulanan kitlesel kıyımlara varan inkâr, asimilasyon ve yasak politikaları olmuştur (Arslan, 2016: 122). Bugüne kadar Suriye'deki Kürtlerin ayrı veya bağımsız bir devlet talebi olmamasını sadece bölgesel boyutlara sahip bir etnik mesele olarak görmek yanlış olacaktır. Bunun yanında, demokratik hakların ihlali ve demokratik yönetim/lerin olmayışının da büyük etkisi bulunmaktadır. Suriye'deki Kürtler kültürel ve dilsel haklar açısından hiç bir zaman azınlık olarak kabul edilmemiş; şiddet ve savaştan azade olmamışlardır (Halhalli, 2015a: 41). Kürtler Suriyeli iktidarlar tarafından asimile edilerek Araplaştırılmış, uzun yıllar sürgüne gönderilmiş, sömürge olarak görülmüş ve fiziksel ve kültürel baskının kurbanı olmuşlardır.

Kürdistan coğrafyasına ve tarihine kısaca değindikten sonra, önce Batı Kürdistan’daki tarihsel gelişmeler/çekişmeler/tartışmalar daha görünür kılma ve Suriye'deki Kürt siyasi aktörler ele alınarak Ortadoğu'da bir halkın uzun süren mücadele pratiğini, kısmen de olsa, Suriye'deki Kürt siyasi partilerle incelenecektir. Bilindiği üzere, Suriye'deki Kürt siyasi hareketi Irak, İran ve Türkiye'deki Kürt siyasi hareketlerinin aksine- 2011 yılında Suriye'ye sıçrayan Arap Baharına kadar- akademik araştırmalarda, uluslararası platformlarda ve 
diplomasi alanındaki faaliyetlerine ilişkin araştırmalarda daha az yer verilmiştir. Dolaysıyla, Suriye'deki Kürt siyasi aktörleri/partileri anlayabilmek için hem Birinci Dünya Savaşı sonrasında Türkiye'deki Kemalist yönetiminin baskıları sonucu göç eden Kürtlerin Suriye'deki konum, arayış ve neler yaptıklarına bakmak, hem de Suriye Kürdistan Demokrat Parti (Partiya Demokrat a Kurdistane li Suriye-PDKS) tarihi bağlamında tartışmak gerekir. Çünkü Kürdistan'ın hiçbir parçasında PDKS kadar komplike siyasi parti bölünmeleri yoktur. Günümüzde Suriye'de aktif olan Kürt siyasi partilerin -Partiya Yekitiya Demokrat, PYD hariç- hemen hemen hepsi 1957 yılında kurulan PDKS'den koparak gelişmiştir. PDKS ve onu takip eden diğer siyasi partiler, Suriye yönetimleri tarafından siyasi parti çalışmaları tanınmamıştır. Ülkenin bütünlüğü ve Arap kimliği için tehdit unsuru olarak görülen bu partilerin hakları sınırlandırılmış, üzerindeki baskılar giderek artmıştır. Suriye'deki Kürt siyasi muhalefet hem komşu ülkelerdeki ayrı bir Kürt devletinin oluşumu için hassas ve 1lımlı davranmış hem de Suriye'de genelde sakin, barışcıl ve demokratik bir mücadele izlemiştir (Schmidinger, 2015 \& Tejel, 2015). ${ }^{1}$ PKK'nin sosyal ve siyasal mirası üzerine 2003 yılında Suriyeli Kürtler tarafından kurulan PYD (Demokratik Birlik Partisi, PYD'nin kısaltması ise Kürtçe adı olan "Partiya Yekîtiya Demokrat") ise Suriye iç savaşının patlak vermesinin ardından Kürt halkının doğal ve demokratik haklarını tanınmadığını gerekçe göstererek ne Suriye rejimi ne de muhalefetle yan yana durmuş, genelde mevcut sorunları silahlı mücadele ile ve mümkün olduğunda da barışçıl ve pragmatik yollarla çözmeyi ilke olarak benimsemiştir.

$\mathrm{Bu}$ çalışmada Suriye'deki Kürt partileri araştırılırken daha çok Suriye Kürtleri konusunda uzman olan Harriet Allsopp'un “The Kurds of Syria: Political Parties and Identities in the Middle East" (Suriye Kürtleri: Orta Doğu'da Siyasi Partiler ve Kimlikler) kitabından ayrıntılı olarak yararlanılmıştır. Bunun yanısıra, bu çalışmaya Jordi Tejel'in kaleme aldığı "Syria's Kurds: History, Politics and Society" (Suriye Kürtleri: Tarih, Siyaset ve Toplum) ve Thomas Schimidinger'in "Krieg and Revolution in Syrisch-Kurdistan: Anaysen und Stimmen aus Rojava" (Suriye Kürdistanı'nda Savaş ve Devrim: Rojava'dan Sesler, Analizler) çalışmadan yararlanılmıştır.

Çalışmanın bundan sonraki bölümlerinde öncelikle Suriye Kürtleri hakkında bilgi verilecek, uzun süren mücadeleri ele alınacak, daha sonrasında ise Suriye Kürt partilerinin konumu, örgüt tarzları, çatı örgütleri ve bölgesel Kürt siyasi hareketleriyle ilişkileri ele alınmaya çalışılacaktır.

\section{Suriye Kürdistanı: Uzun Süren Mücadeleler}

Suriye Kürtlerinin sayısı yaklaşık olarak iki buçuk milyon (1.9 milyon vatandaş, 350 bin ecnebi, 250 bin kayıt diş1-kimliksiz) tahmin ediliyor ki bu rakam 22 milyonluk toplam Suriye nüfusunun \%11-12'sine tekabül ediyor (Gunter, 2011 \& Bengio, 2014). ${ }^{2} \mathrm{Bu}$ rakamlar

\footnotetext{
${ }^{1}$ Siyasi tercihler yapılırken silahlı mücadele Suriye'nin dışındaki Kürt coğrafyasında siyasi hareketin başlıca başvurulan biçimiydi. Oysa Suriye Kürt partileri Suriye rejimine karşı kısa ve başarısız bir Kürdistan Özgürlük Hareketi (Tevgera Azadiya Kurdistan) deneyimi dışında hiç bir zaman silahlı mücadele yürütmedi. Daha fazla bilgi için, bkz: (Schmidinger, 2015) \& (Taştekin, 2016).

${ }^{2}$ Suriye anayasası Suriye Arap Cumhuriyeti'ndeki vatandaşları Arap olarak tanımlamaktadır. Ayrıca, Suriye'de sağııkı nüfus sayımı yapılmadığından ve Kürt varlığı ve kimliği inkâr edildiğinden kesin resmi sayılar ve istatistikler bulunmamaktadır.
} 
aynı zamanda Kürtlerin Suriye'deki en büyük Arap olmayan azınlık olduğunu göstermenin yanında Suriye'de pek çok Kürt en temel haklardan mahrum edilmesi ve Suriye vatandaşlığından çıkarılmasının sonucunda sayılarını tahmin etmeyi zorlaştırmıştır. Neredeyse tamamı Kürtçenin Kurmanci lehçesini konuşan Kürtlerin kahir ekseriyeti Sunni çok az bir kesimi ise Ezididir. Suriye'de büyük azınlık olmasına rağmen Kürtler daha az başarılı organize olmuştur. Diğer komşu ülkelerdeki Kürtlere göre siyaset, askeri, kültürel ve ekonomik yönden daha az gelişmişler.

Türkiye ile en uzun kara sınırına sahip olan Suriye'nin genelde Kuzey bölgelerinde sınıra paralel olarak yoğunlaşan Kürtler başlıca Nuseybin karşısında bulunan Kamışlı (Kürtçe: Qamişlo) ilçesi, güneyde daha iç kesimlerde bulunan Haseki ili, Silopi karşısında bulunan Tırbe Spi (bu bölgeler Cizire olarak da adlandırılır), Mardin karşısında bulunan Amude, Kızıltepe karşısında bulunan Dırbesiye, Ceylanpınar karşısında Sere Kaniye (Resul Ayn), Akçakale karşısında bulunan Girê Spî (Talabyad), Suruç karşısında bulunan Kobanê (Ayn el Arap) ve daha batıda yer alan Afrin bölgeleri Kürt Dağı (Kürtçe Çiyaye Kurdan, Arapça Cebel-ül Akrad) dâhil ve bölgeler arasında kalan çok sayıda köyde yaşamaktadır (Bingöl, 2013: 50).

Çoğunluğu ülkenin kuzeydoğusunda Türkiye ve Irak sınırına yakın bölgede (Fransızlar bu bölgeye 'le Bec de Canard', yani ördekgagası diye adlandırır) yaşayan Kürtler ayrıca Şam ve Halep'te çok sayıda bulunmaktadır.

Batı Kürdistanın konum ve tarihsel arkaplanını anlamanın en önemli yollardan birisi geçmişte Osmanlı yönetimi sonrası ilişkilerine ve isyan sonrasında Türkiye'deki baskılardan göç edenlerin Suriye'de neler yaptıklarına bakmak da gereklidir. 1920-1946 yılları arasında Fransız manda yönetimi döneminde Kürtlerin özerklik talebinin (Tejel, 2009: 27-28 \& Schmidinger, 2015: 54-55) ${ }^{3}$ kabul edilmemesinin ardından Kürtler Suriye vatandaşlığına kabul ettirilmiştir. Çok büyük baskılara maruz kalmaksızın sessiz bir şekilde yaşamlarını idame ettirmişlerdir. Ancak, sınırlar serxet (demiryolu hattı ile sınır bölünür: sınırın üstü Türkiye) ve binxet (sınırın altı Suriye) olarak çizilirken Türkiye'deki (Sason, Şeyh Said, Koçgiri, Dersim, Ağrı vb.) Kürt İsyanlarının ardından Kemalist rejimine karşı mücadele eden aşiret liderleri, aydın dindarlar ve Kürt entellektüelleri Suriye'deki hareketi canlandırmaya ve sinerji kazandırmaya yönelik bariz roller üstlenmişlerdir. Özellikle Suriye'deki Kürt hareketin öncüsü olan Xoybûn (Bağımsızlık) Örgütü 1927'de Lübnan'da kurulmuş ve Suriye'de (özellikle Şam'daki sürgündeki Kürt entellektüelleri tarafından) genişletirilmiş ve öncelikli olarak Türkiye'ye karşı siyasi ve kültürel faaliyetlerde bulunmuştur. ${ }^{4}$ Oysa Fransız manda döneminde Kürtlerin, yerel iktidar alanlarını kurmakla beraber, siyasal manevra alanı sinırlıydı. Xoybûn örgütü Suriye'de manda yönetiminde sağlanan haklarla yetinebileceğini ve bu haklar için siyasi bir talepte bulunulmacağını ifade etmişti (Kutschera, 2013: 114). Bu ifadelelerle Xoybûn Örgütü/Komitesi Fransız ve İngiliz yönetimleriyle iyi geçinme, politik sorun yaratmadan kültürel hareketlerini (kültürel talepler ekseninde siyasi ve diplomatik faaliyetlere ağırlık verildi ki bu da Xoybûn'un milliyetçi söylemini çok sayıda Kürdün

\footnotetext{
${ }^{3}$ Bunun nedeni Fransızların, Kürtler konusunda hassasiyeti olan Türkiye ve Irak'ın tepkisini çekmek istememesi olabilir.

${ }^{4}$ Cemilpaşazadeler, Bedirxaniler, ìnsan Nuri Paşa, Haco Ağa, Cegerxwin, Nureddin Zaza, Ferzende, Memduh Selim, Şeyh Ali Rıza, Osman Sabri, Mehmet Şükrü Sekban gibi kişiler ve aileler Xoybûn örgütünün kurulmasında ve faaliyet göstermesinde önemli rol oynadılar. (Bolme, 2015)
} 
hafizasına ve bilincine yerleştirdi) $)^{5}$ iyi bir şekilde koruyup geliştirmeyi amaçlamış olabilirler. Xoybûn hareketinin dağılması ve 1940'ların sonuna doğru Kürt siyasi hareketinin çeşitli siyasi kesimlerini bir araya getirememesi Cegerxwin, Qedri Can, Osman Sabri, Reşid Hamo, Muhammed Ali Hoca gibi bazı önemli Kürt şahsiyetleri Suriye Komünist Partisine yöneltmiştir. Fransızların getirdiği seçim sayesinde Kürt siyasetçiler 1947, 1949 ve 1957 dönemlerinde milletvekili ve başbakan olarak seçilmişlerdir (Bulut, 2015a: 284). Daha da önemlisi, kendisi de Kürt olan General Hüsni Zaim rejimin güvenliğini sağlamak için 1949 yılında darbe yapmış ardından yine Kürt olan Edip Şişek tarafından iktidarına son verilip idam ettirilmiştir. General Şişek Kürtlerin ve gayrimüslimlerin sosyal ve siyasal haklarını kısıtlarken kendisi de 1954 yılında askeri bir darbeyle devrilmiştir.

1950'lerin ikinci yarısına kadar, çoğunlukla az değer görmüş olan Suriye Kürtleri, sosyal, kültürel ve siyasi haklarından mahrum edilmelerinden ötürü Suriye'deki Kürt milliyetçiğini veya hareketini gündemine alan bir Kürt partisi henüz oluşturamamışlardır. Diğer bir ifadeyle, 1946-57 yılları arasında Kürtlerin haklarını savunacak bir örgütleri yoktur. Bu durum 1950'lerin ikinci yarısından sonra değişti. Irak’taki değişimler ve yükselen Arap milliyetçiliğine tepki olarak PDKS Mustafa Barzani ve dönemin Irak KDP Politbüro üyesi olan Celal Talabani desteğiyle kuruldu. Başlangıçta "Suriye Kürtlerinin Demokrat Partisi" adıyla kurulsa da daha sonra, yani 1960'ta "Suriye Kürdistanı Demokrat Partisi” olarak değişmiştir. Ancak, sekretaryasını Osman Sabri ve başkanlığını Nureddin Zaza'nın yaptığı parti, Mısır ile kurulan Birleşik Arap Cumhuriyeti döneminde partinin manevra alanı sınırlandırılmış, kendileri ve yönetim kurulu üyeleri de dâhil yaklaşık 5000 sempatizanıyla birlikte “bölücülük”ten yargılanmıştır ve parti kapatılmıştır (Allsopp, 2015).

1960'ların ortasından itibaren tarım reformu gerekçe gösterilerek 120 bin Kürt köylünün topraklarına el konuldu ve aynı zamanda bunların vatandaşlık hakları elinden alındı (Minorsyk \& Bois, 2008: 138). Bu minvalde 1962 nüfus sayımı ve 1963'de Baas rejimin iktidara gelmesiyle uygulanan “Arap Kuşağ1/Kemeri”, bugünkü bölgesel birçok önemli sorunun temelini oluşturmaktadır.

Baas rejimi başlangıcından itibaren-1963 OHAL yasası çıkararak- "Arap Kuşağı” uygulamış, Esad yönetim(ler)inde tamamlamıştır. 1973 Anayasası'ndan da anlaşılacağı üzere Kürtlerin ve diğer azınlıkların haklarında bir ilerleme kaydedilemedi. 1970-76 yılları arasında muazzam bir "Arap Kuşağı” uygulamasıyla Irak-Türkiye sınırı çevresinde örnek 41 modern tarım köyü kurularak Kürtlerin yerine yaklaşık 25 bin Arap aile yerleştirildi (Schmidinger, 2015: 82). Bununla beraber, Suriye yönetimi 1963 'ten beri yürürlükte olan OHAL ile Arap milliyetçiliğini Kürt dili ve Kürt folkloru üzerinde tehdit olarak uygulamış, kısıtlamaları da içeren yasalarla Kürt kimliğini ve direniş manevrasını daraltmıştır.

Kürtleri zor durumda bırakan bu uygulamalara ek olarak Hafız Esad, 1970'li yılların sonlarından başlayarak 1998'e kadar PKK (Partiya Karkeren Kurdistan-Kürdistan İşçi Partisi)'ye destek vererek Suriye'de kamp kurmasına göz yummuş, Türkiye ile aralarındaki (dış politika) meselelerde bir koz olarak kullanmıştır. Kürt meselesinin bölgesel ve ulusaşırı tabiatı ülkelerin ilişkilerinde önemli rol oynamıştır. Bu dönemde ise Suriye'de Kürtlerin

\footnotetext{
${ }^{5}$ Her ne kadar işgal döneminde çok ciddi kazanımlar elde edilmese de, pek çok yönü ve yaklaşımları ile Kürt hareketine yeni bir soluk getirmiştir ve kendinden sonraki örgütler için önemli bir birikim bırakmıştır. Örneğin, kurulan çeşitli Kürt dernekleriyle medreseler, Hawar ve Roja Nu dergilerin dile getirdiği Kürt aidiyet, hissiyat ve fikir Kürtleri yeni bir evreye taşımıştır.
} 
rejime karşı herhangi bir girişiminin olmaması Suriye'deki PKK varlığıyla açıklanabilir. Suriye ile yakın ilişkileri olan PKK Suriye Kürtlerinin dikkatini Türkiye ve Irak'a yönlendirmeyi başarmıştır. Böylece, Suriye yönetimi Suriye Kürtlerinin Irak ve Türkiye'deki Kürt hareketlerinin taraftarları olarak kutuplaşmasını teşvik etmekte başarılı oldu (Tejel, 2015: 153). Ankara ile Şam arasında 1998 yılında Adana Protokolünün imzalanmasıyla PKK'ye destek de kesilmiş oldu. Bununla beraber, Kürtlerin rejime yönelmelerini yönündeki baskı da kalkmış oldu. Ancak, başlarda kendi içlerindeki yönelim mücadeleleri ve liderlerinin kaybıyla meşgul olan Suriye'deki PKK kadrosu PYD (Partiya Yekitiya Demokrat) adıyla ancak 2003'te kurulabildi; bu partiyse rejimin desteğini asla alamadı, hatta eski Kürt partilerine göre çok daha şiddetli baskılara maruz kaldı (Schmidinger, 2015: 92).

12 Mart 2004'te Kürt ve Arap taraftarlar Kamışlı ilçesinde bir futbol maçı üzerinden çıkan kavgadan sonra 36 Kürt öldü, 160 tanesi yaralandı, 2.000'den fazla gözaltına alınan Kürt işkence gördü (Human Rights Watch, 2009). Bu olaylar Kürtlerin ilişkilerinde yeni bir dönem oluşturdu ve Suriye hükümetine karşı Kürt intifadası ya da serhildan (Kürtçe isyan) olarak da bilinen Kürt ayaklanmasına neden oldu. Beşşar Esad'ın Kürtlerin haklarını iade edileceğini beyan etmesine rağmen bu konuda bir gelişme yaşanmazken Kürt siyaseti sadece iç dinamiklerle değil; sınır ötesi dinamiklerden de etkilendi. Irak'ta Federatif Kürt Devleti Suriye Kürtlerin faaliyetlerini ve umutlarını da canlı tutmuştur.

Nihayetinde Arap Baharı adı verilen isyan dalgası 2011'in Baharında Suriye'ye de sıçradı. Kürt siyasi partiler bu dönemden itibaren rejim sonrası olası federasyon gibi talepleri dillendirmeye/tartışmaya başladılar. Barzani veya KDP'ye yakın Suriyeli muhalif Kürt partiler yaşanan süreçte ortak tutum ve politika geliştirmek için "kendi kaderini belirleme hakkı, Kürt halkının taleplerini güvence altına alacak-koruyacak bir Anayasa ve demokratik bir Suriye" gündemiyle Ocak 2012'de Erbil şehrinde Mesud Barzani'nin liderliğinde bir toplantı gerçekleştirildi. Ancak, PYD bu toplantıya katılmadı. Daha sonra PKK'ye yakınlığıyla bilinen Meclisa Gel (TEV-DEM veya Halk Meclisi) ile birlikte hareket eden Suriye Kürt partilerinin oluşturduğu ittifak olan Suriye Kürt Ulusal Konseyi (Encumena Niştimani ya Kurdi li Suriyeye-ENKS) ile beraber 9-10 Temmuz 2012'de Erbil'de gerçekleştirilen toplantıya katıldı. Bunun ardından, Suriye'de yaşanan çatışmalar sürecinde PYD, rejim karşıtı faaliyetlerden uzak durdu ve bu tutumu nedeniyle yoğun bir şekilde eleştirildi. Aynı zamanda Suriye Ulusal Konseyi içerisinde de yer almayan PYD kendi savunma güçlerini Halk Koruma Birlikleri (Yekîneyên Parastina Gel - YPG) oluşturarak/güçlendirerek iç çatışmaların yoğunlaştı̆ğ 2012 Temmuzunda silahlı bir çatımaya girmeksizin Kuzey Suriye'deki birçok Kürt yerleşim bölgesinin (rejimin çekilmesiyle) güvenliğini sağladı. Kasım 2013'te Suriye'deki bir dizi diğer Kürt politik grupla birlikte PYD, Kürt yarı-özerk yapı üç demokratik kantondan oluşan- Afrin (Efrîn), Cizîre (C1zîrê) ve Kobani (Kobanê)- kontrol ederek bu bölgelerde geçici bir hükümet kurdu ve adını Rojava olarak duyurdu.

\section{Suriye'deki Kürt Siyasi Partiler}

Daha çok insan haklarıyla uluslararası gündeme gelen Suriye'deki Kürtlere ilişkin Suriye Kürt siyasi partileri ve Suriye Kürt hareketi eksenli araştırmalar çok azdır. Ancak, Kürt grupları 2011'de iç savaşın patlak vermesinin ardından Suriye rejimine karşı Suriye'deki en 
büyük toprak kazanımlarından birini kontrol ederek dünya kamuoyuna dikkatini çekmeyi başarabilmiştir. Bunun yanında, DAİŞ (IŞID- Kürtçesi: Dewleta İslamî ya Iraq û Şamê, Türkçesi: Irak Şam İslam Devleti) ile mücadelesinde pek çok uluslararası gücün desteğini sağlarken uluslararası basında da yer edinebildi.

Kültürel faaliyetlerde pek çok birikimleri olmasına rağmen Suriye Arap Cumhuriyeti'ndeki Kürtler daha az başarılı organize olmuş ve diğer komşu ülkerdeki Kürtlere göre siyaset, askeri ve ekonomik yönden daha az gelişme göstermiştir. Birinci Dünya Savaş1 sonrasında Orta Doğu'da sınırların çizilmesiyle bölgede yaşayan Kürtlerin de bölünmesine/parçalanmasına neden olmuş, Irak, İran ve Türkiye'den daha az sayıda Kürt, Fransız mandası altındaki Suriye sınırları içinde kalmıştır. 1920-1946 yılları arasında Fransız manda yönetimi döneminde Xoybûn hareketi/örgütü öncülüğündeki Kürtler Suriye'de kültürel, siyasi ve askeri mücadeleye yeni bir soluk kazandırmıştır. Daha önce de belirtildiği gibi Türkiye'de 1920'li ve 1930'lu yıllardaki (Sason, Şeyh Said, Koçgiri, Dersim, Ağrı vb.) Kürt İsyanlarının ardından Kemalist rejimine karşı mücadele eden aşiret liderleri, aydın dindarlar ve Kürt entellektüelleri Kürdistanın batısındaki hareketi canlandırmaya ve sinerji kazandırmaya yönelik bariz roller üstlenmişlerdir. Suriye Arap Cumhuriyetinin kurulmasının ardından ise devletin alt kimlikleri siyasi güç kazanmasını engeleyen/rededden anlayışı nedeniyle politik açıdan güç kazanamamışlardır. 1946-57 yılları arasında Ortadoğudaki diğer bölgelerinde yaşanan olumsuz gelişmelerle beraber Suriye'de de Kürtlerin haklarını savunacak bir örgütleri olmamıştır . Böylece Suriye hükümeti Kürt bölgelerini- etnik ve dil açısından ayrı bir grup olan Kürtlerin, Türkiye ve Irak sınırlarındaki bölgelerinin yanında ülkenin diğer bölgelerindeki birkaç şehirde ， özellikle Şam ve Halep gibi önemli yerleriniekonomik, kültürel ve siyasi olarak entegrasyonunu sağlamıştır.

Bununla birlikte, Suriye hükümetinin kurulmasında ve sonrasında önemli Kürt asıllı politikacılar, bürokratlar dahil olmak üzere birçoğu devlet kurumunda görev almıştır. Suriye'de ilk askeri darbeye öncülük eden ve 1949 'da cumhurbaşkanı olan Hüsnü El-Zaim Kürt asılllydı. 1954'te Suriye Parlamnetosu'na seçilerek Arap dünyasının ilk komünist milletvekili olan ve aynı zamanda Suriye Kommunist Partisi başkanlığını yürüten Halid Bekdaş ve eski devlet müftüsü Ahmed Kiftarro gibi birçok etkili din adamı da Kürt asıllıydı.

Suriye hükümeti tarafından resmen tanınmasa da 1957'de "Suriye Kürtlerinin Demokrat Partisi" adıyla kurulan daha sonra, yani 1960'ların başında "Suriye Kürdistan Demokrat Partisi (Kürtçe: Partîya Demokrata Kurdistan a-Sûriye-PDKS)" bugün bir kaç parti hariç neredeyse diğer tüm partilerin kaynağıdır. Kürt partileri 1960'lı yılların ortalarında Kürtlerin özerkliği için çalışıp-çalışmama durumlarına göre veya Koünist Partilerle ortak hareket edipetmeme durumlarına göre pekçok gruplara bölünmüşlerdir/ayrılmışlardır.

Farklı bölünmelerin/fraksiyonların nedenleri daha sonraki bölümde değinileceği gibi dış (bölgedeki egemen güçler, Suriye'deki Kürt partilerin Irak ve Türkiye'deki Kürt partilerine yakınlığı ve bağımlılığı, Suriye rejiminin yasakları ve işbirlikleri) ve iç faktörler (toplumsal, düşünsel ve kişisel çıkarlar) olarak açıklanabilir. Neredeyse bütün partiler yasadışı olması sebebiyle yapıları çok zayıf kalmış ve gizli hücreler şeklinde örgütlenmişlerdir (Schmidinger, 2015: 102). Tabela partisi olmaktan öteye geçemeyen çoğu parti halk tabanından yoksun, bazı akraba ve arkadaşların bir araya gelerek kurduğu oluşumlardır (Bingöl, 2013: 52). Suriye'de faaliyet gösteren Kürt partileri çoğunlukla merkez olarak Cezire 
bölgesini, özellikle Kamışı ilçesini seçerken PYD Cezire bölgesinin yanında Kobanê, Afrin, Girê Spî gibi bölgelerinde konumlanarak Kuzey Suriye'nin neredeyse tamamını kontrol edebilmektedir. Parti faaliyetleri aynı zamanda Avrupa'ya (diasporaya) da taşınarak orada yaşayan Kürtlerin aracılığıyla Avrupa ülkelerinin Suriye Kürt politikasına kayıtsız kalmadığını gösteriyor.

Suriye Arap Cumhuriyeti'nde aynı kökenten (PDKS) türeyen etkili Kürt muhalefet partilerin çoğu kendi içlerinde istikrarsızlık ve liderlik çekişmeleri olmasına rağmen pek çoğu günümüze kadar faaliyetlerini sürdürebilmiştir. Partiler hakkında özet bilgi müteakip bölümlerde sunulmaktadır.

\subsection{Suriye'deki Kürt Siyasal Partilerin Genel Görünümü}

PDKS (Suriye Kürdistan Demokrat Partisi) Haziran 1957'de kuruldu. Parti programında Kürtlerin etnik bir grup olarak tanınması ve demokratik bir yönetimin esas alınması hedeflenmiştir. Arap milliyetçiliğine tepki olarak kurulan PDKS'nin 1960 yılında yöneticileri tutuklandı; parti başkanı Nureddin Zaza'nın Suriye'den çıkması istendi. 1965 yılında kültürel ve sosyal haklara odaklanmak isteyen Zaza'nın öncülüğündeki grubu ile siyasal mücadeleye odaklanmak isteyen Osman Sabri'nin grubu olmak üzere PDKS ikiye bölündü. ${ }^{6}$ Irak’ta liderliğini Molla Mustafa Barzani'nin yaptığı Kürdistan Demokrat Partisi (KDP) ile yakın ilişki içinde olan PDKS, 1960'larda kendi içinde bölünmeler yaşaması üzerine Mustafa Barzani tüm kesimleri Irak Kürdistanı'na davet ederek partiyi yeniden birleştirme girişiminde bulunsa da olumlu bir netice alamamıştır. Toplantılar sonrasında Deham Miro parti başkanlığına seçildi, daha sonra 1972'de PDKS başkanlığına yeniden seçildi.

1965 yılında başlayan bölünmeler sonucu parti, gücünü ve etkinliğini yitirse de çep (sol) ve rast (sağ) fraksiyonlara bölünmüş ve pek çok değişimler yaşamıştır. 1965 yılında PDKS'den iki parti çıkmıştır: PDKS (sol kanat) Osman Sabri (1969-2003 yıllarında Salih Bedrettin ve 2003-2005 yıllarında ise Mustafa Cuma himayesinde) ve PDKS (sağ kanat) Abdülhamit Hacı Derviş'in liderliğinde olmuştur (Kurdswatch, 2011). Şunu da belirtmek gerekir ki, parti ideolojik farklılıklardan ziyade biçimsel ve lider değişimleri daha çok ön planda yer almıştır. Örneğin, PDKS'den ayrılıp (Partiya Demokrata Pêşverû li Suri) Suriye Kürt Demokratik İlerici Partisini kuran Abdülhamit Heci Derviş ${ }^{7}$ (ki kendisi de bir aşiret reisidir) ve Irak Kürdistan Özerk Bölgesi’nden, özellikle Celal Talabani’nin partisi (Yekîtîya Niştimanîya Kurdistan) Kürdistan Yurtseverler Birliği'nden destek alsa da kendini sağ kanatta konumlandırmıştır (Tejel, 2015). ${ }^{8} 1965$ yılından bu yana genel sekreterliğini yürüten deneyimli siyasetçi Derviş Suriyeli Kürtler arasında kesintisiz liderliğe sahip olmanın yanında özellikle Celal Talabani'nin partisi Kürdistan Yurtseverler Birliği'nden destek bulmuştur (ORSAM, 2012: 18).

\footnotetext{
${ }^{6}$ Hem Dr. Nureddin Zaza hem de Osman Sabri Şeyh Said isyanının başarısızlıkla sonuçlanması üzerine Suriye'ye geçmiş ve burada önce Xoybûn ve sonrasında ise PDKS'nin kuruluşunda önemli roller üstlenmişlerdir.

${ }^{7}$ Abdülhamit Heci Derviş, solcu olmamasına rağmen 1965'te okul arkadaşı Celal Talabani'nin Marksist kampına katılmıştır.

${ }^{8}$ PDKS'nin sağ kanadından türeyen PDPKS 1970-1983 yılları arasında PDKS ismini kullanmaya devam etmiş, 1983 yılında alınan kararla ismini Partiya Demokrata Pêşverû ya Kurd li Sûriyê olarak değiştirmiştir.
} 
1965 yılında yaşanan parçalanmanın ardından PDKS'nin ana eksenini oluşturarak bugüne gelen benzer isimli 4 fraksiyondan/partiden biri de 1981 yılında yapılan isim değişikliğiyle günümüzde halk arasında daha yaygın olarak kullanılan El Partî'dir. ${ }^{9}$ Partiye sırasıyla Deham Mîro (1970-1973) Hemîd Sîno (1973-1976) Mustafa İbrahim (1976-1977) İlyas Ramazan (1977-1978) Kemal Ahmed (1978-1996) Nasreddîn İbrahim (1996-1998) Muhammed Nezîr (1998-2007) başkanlık etmiştir. 2007 yılından bugüne kadar ise PDKS'ye Abulhakim Beşşar liderlik etmektedir. Günümüzde liderliğini Abdulhakim Beşşar'ın yaptığı El Partî'den (PDKS) 1975 yılında ayrılarak aynı isimle yoluna devam eden bu partiye 1975-1997 yılları arasında Şêyh Muhammed Bakî liderlik etmiştir. 1997 yılından itibaren ise partinin başkanı günümüzde de bu görevi sürdüren Cemal Şêyh Bakî'dir. Yine, Nasreddîn İbrahim El Partî'den ayrılmadan önce 1996-1998 yılları arasında partinin başkanıydı. 1998'de El Partî'nin başkanlığına Muhammed Nazir Mustafa'nın gelmesi Nasreddîn İbrahim'in El Partî'den ayrılmasında etkili olmuştur. Benzer ismi taşıyan sonuncu grup ise 2014 beri Abdurrahman Aluci'nin liderlik ettiği PDKS El Parti'dir. Aluci’nin ölümü üzerine partiyi Lazgin Mahmud Fahri yönetmektedir. PDKS'den ayrıldıktan sonra kendisini diğer partiden ayırmak için bu ismi kullanmıştır.

Şunu da belirtmek gerekir ki 7 Nisan 2014 tarihinde Kürdistan Bölgesel Yönetimi (KBY) lideri Mesud Barzani'nin teşvikiyle, Suriye'deki dört siyasi parti, Abdülhakim Beşşar liderliğindeki Suriye Kürt Demokrat Partisi (El-Parti), Mustafa Cuma başkanlığındaki Azadi Partisi, Mustafa Oso liderliğindeki Azadi Partisi ve Abdülbasit Hemo liderliğindeki Kürt Birlik Partisinden oluşan partiler, "Suriye Kürdistan Demokrat Partisi" bünyesinde birleşti ve başkanlığına Suud Mele seçildi. Böyle bir birleşmenin gerekliliğini gazeteci-yazar Faik Bulut, Suriye Kürdistanı'nda egemen güç haline gelen PYD'ye karşı bir önlem ve icabında alternatif bir güç olarak açıklamaktadır (2015b: 100). Anadolu Ajansı'na konuşan partinin Kürdistan Bölgesel Yönetimi (KBY) temsilcisi Nawaf Rashid, ABD liderliğindeki uluslararası koalisyonun korumasıyla Suriye'ye gönderilmek üzere 10 bin Peşmergenin KBY'de eğitildiğini ifade etmiştir (Syrian Peshmerga to Return Home After Training in Iraq, 2017).

Suriye Kürt Demokratik Vatansever Partisine (Partiya Welatparêz a Demokrat a Kurdî li Sûriyê) 1998 yılında PDKS'nin sağ kanadından liderlik mücadelesi sonucu ayrılan Tahir Sifuk liderlik etmektedir.

1992'de PDKS'den ayrılarak kurulan bir başka sağ kanat partisi ise eskiden PKDS'de üst düzey yönetici olan Aziz Davud'un öncülüğündeki Kürt Demokrat Eşitlik partisi (Partiya Wekhevî ya Demokrat a Kurdî li Sûriyê)'dir. Bu partiyle diğer partiler arasında önemli ideolojik ya da örgütsel fark yoktur (Bulut, 2015b: 97).

PDKS'nin sol kanadı Osman Sabri'nin ardından, 1975-1991 yılları İsmet Sayda (daha sonra 1991-1993 yıllarında Yusuf Dibo ve 1994-2005 yıllarında ise Hayreddin Murad) Suriye Kürt Demokratik Sol Partisini (Partiya Çepa Demokrata Kurdî li Sûriyê) yönetmiştir. 1980 yılında ise Suriye Kürt Halkın Birliği Partisi (Partiya Hevgirtina Gelê Kurd li Sûriyê) olarak adını değiştirdi. Bu partiye 1970-2003 yılları arasında Salih Bedreddin 2003-2005 yılları arasında ise Mustafa Cuma liderlik yaptı. 2005 yılında ise alınan bir kararla bu partinin devamı niteliğinde olan Suriye Kürt Özgürlük Partisi (Partiya Azadî ya Kurdî li Sûriyê)- parti siyasi platformlarda Azadî olarak da bilinir- kuruldu ve sekreterliğini Hayreddin Murad

\footnotetext{
${ }^{9}$ Partiya Demokrata Kurd li Sûriyê-Suriye Kürt Demokrat Partisi
} 
yürütmektedir. Ekim 2011 sonunda Azadî ikiye ayrıldı: O zamandan bu yana, aynı isme sahip iki partiden biri Hayreddin Murad (daha sonra Mustafa Hıdır Oso) diğeri ise Mustafa Cuma önderliğinde. $^{10}$

1990-1993 y1lları arasında Sabhatullah Seyda liderliğindeki Suriye Kürt Emekçiler Partisi (Partiya Zehmetkeşanên Kurd li Suriyê), Muhittin Şeyh Ali liderliğindeki Suriye Kürt İşçi Partisi (Partiya Kar a Demokrat a Kurdi li Suriye) ve İsmail Ammo liderliğindeki Suriye Kürt Demokrat Partisinin (Partiya Demokrata Kurdi li Suriye) bir araya gelerek oluşturduğu Suriye Birleşik Kürt Demokrat Partisine (Partiya Demokrata Kurdî ya Yekbûyî li Suriye) İsmail Ammo liderlik yaptı (Schmidinger, 2015: 254-255).

PKDS içerisinde yaşanan bölünmenin ardından sol kanattan türeyen partilerden biri olan Kürt Demokrat Birlik Partisi (Partiya Yekîtiya Demokrata Kurdî li Suriyê), Yekîti olarak da bilinir, 1993 yılında Ismail Ammo liderliğinde kuruldu. Başkanlığını 1993-2001 yıllarında İsmail Ammo ve 2001 yılından beri ise Muhittin Şeyh Ali yapmaktadır. Parti içerisinde yaşanan anlaşmazlıklar sonucunda partiden kopmalar yaşanmış ve 1998 yılında Muhammed Musa Muhammed öncülüğünde Suriye Kürt Sol Partisi (Partiya Çepa Kurdî li Suriyê) 1999 yılında ise Suriye Kürt Birlik Partisi (Partiya Yekitiya Kurdî li Suriyê) kurulmuştur (Schmidinger, 2015). ${ }^{11} 1999$ yılında kurulan Suriye Kürt Birlik Partisine sirayla Abdulbaki Yusuf (2000-2003), Hasan Salih (2003-2007), Fuad Aliko (2007-2010), İsmail Hami (20102013) ve İsmail Biro (2013- günümüze) liderlik etmiştir. ${ }^{12}$

Yine sol kanattan türeyen Suriye Kürt Sosyalist Partisi (Partiya Sosyalist a Kurdi li Suriye) ise 1977 yılında Muhammed Salih Gedo tarafindan kuruldu ve 2002 kadar siyasi faailiyetlerine devam etti. 2004'te Muhammed Musa'nın partisinde başkan yardımcılı̆̆ görevini yürüten Salih Gedo ve bir kısım politbüro üyesi partiden 2012 yılında anlaşmazlık sonucu ayrılarak benzer isimli Suriye Kürt Sol Demokrat Partisi'ni (Partiya Çepa Demokrat a Kurdî li Suriyê) kurdular ve günümüzde sekretaryasını halen Gedo yürütmektedir.

PDKS bölünmelerin dışında bağımsız partiler de ortaya çıktı: Demokratik Birlik Partisi (Partiya Yekitiya Demokrat), Suriye Kürt Demokratik Uzlaşı Partisi (Rekeftina Demokrat a Kurdi li Suri) ve Suriye Kürt Gelecek Hareketi (Şepela Pesroje ya Kurdi li Suriye). 2003 yılında Fuad Ömer (2010'dan sonra Salih Müslim ve 2012'den itibaren ise Asya Abdullah ile beraber) ${ }^{13}$ tarafından yönetilen parti diğer Kürt partilerinden daha etkin ve daha geniş bir alana yayılan bir tabana sahip olmasında askeri kolu olan Halk Koruma Birliklerinin (Yekîneyên Parastina Gel - YPG) payı çok büyüktür (International Crisis Group, 2013). Daha kurulduğu yılda partiden anlaşmazlık sonucu ayrılan Kemal Şahin öncülüğünde bir grup Suriye Kürt Demokratik Uzlaşı Partisini (Rekeftina Demokrat a Kurdi li Suri) kurdu.

\footnotetext{
${ }^{10}$ Anlaşıldığı üzere bugün Suriye Kürdistanı'nda iki Azadî partisi var. Hayrettin Murad kısa süre sonra güç kaybetmiş ve yerini Mustafa Hıdır Oso'ya bırakmak zorunda kalmıştır. Özetle, bugün birisi Mustafa Cuma diğeri ise Mustafa Hıdır Oso liderliğinde iki Azadi partisi bulunmaktadır.

${ }^{11}$ Yekîti olarak da bilinir.

12 ibrahim Bıro aynı zamanda ENKS'nin başkanıdır.

1316 Haziran 2012'de "Suriye'ye demokrasi, Batı Kürdistan'a özerklik" sloganıyla düzenlenen 5. kongreyle birlikte eş başkanlık sistemi uygulamaya konuldu. Salih Müslim ve Asya Abdullah parti eş başkanlığına seçildiler. Hemen hemen tüm partilerin kadın üyelere sahip olduklarını iddia etmelerine rağmen, Suriye-Kürt partilerinde PYD hariç siyaset alanı erkeklerin himayesinde/kontrolünde kalmaya devam etmiştir. Buna ek olarak, içinde kadınlarında yer aldığı silahlı güçler Suriye'nin kuzeyindeki bazı bölgeleri kontrol etmekten sorumludur.
} 
Ancak Kemal Şahin'in Şubat 2005'te Irak Kürdistanı'nda öldürülmesinden sonra parti pek çok başkan değiştirdiyse de etkili bir hareket olarak varlığını sürdüremedi.

Suriye Kürt Gelecek Hareketi (Şepela Pesroje ya Kurdi li Suriye) PDKS kökenli parti geleneğinin dışından gibi görünse de daha önce Salih Bedreddin'in partisi içerisinde görev almış ve 1999 yılında partiden ayrılan Mişel Temo tarafından 2005'te kurulmuştur. 7 Ekim 2011 tarihinde Temo'ya yapılan suikast sonrasında parti aynı isimle anılmak üzere Rezan Bahri Şeyhmus ve Cemal Molla Mahmud liderliğinde ikiye bölündü.

\subsection{Suriye Kürt Siyasi Partilerinin Çatı Örgütleri}

Siyasi bezginlik, kişisel çıkarlar ve yaşanan anlamsız ideolojik farklılıklar ardından parçalanan/bölünen Kürt partileri zaman zaman siyasi ve diplomatik hareketi birleştirmeye ve çatı örgütleri kurmaya çalıştı fakat yeterli olamadılar. 1992 yılında kurulan Suriye Kürtleri Demokratik Birliği/İttifakı (Hevbendi ya Demokrat a Kurdi li Suriye), 1996 yılında kurulan Suriye Kürt Demokratik Yurtsever Cephesi (Eniya Niştimanî ya Demokrat a Kurdî li Sûriyê) ile birlikte Şam Beyannamesini 2005'te imzaladılar (International Crisis Group, 2013 \& Allsopp, 2015 \& Schmidinger, 2015). ${ }^{14} 2006$ yılında Şam Beyannamesini imzalamayan partiler ise Kürt Koordinasyon Komitesi (Komita Tensiqe ya Kurdi) çatısı altında birleştiler. Yine 30 Aralık 2009 tarihinde Suriye Kürt Siyasi Konseyi (Encumena Siyasi ya Kurdi li Suriyeye) oluşturuldu (Allsopp, 2015: 96). Schmidinger, bu ittifakların oluşmasını ve parçalanmasını dış faktörlere dayandırmaktadır: Suriye Kürtleri Demokratik Birliği Abdulhamid Hacı Derviş öncülügünde Irak Kürdistan Yurtseverler Birliği (Yekîtîya Niştimanîya Kurdistan ya da Yetîkîya Niştimanperwerê Kurdistan / KYB) bağlı hareket ederken Suriye Kürt Demokratik Yurtsever Cephesi liderliğindeki Abdülhakim Beşşar ise Iraq Kürdistan Demokrat Partisi (Partîya Demokrata Kurdistan a Irak/KDP) ile iş birliği içerisinde olmuştur (2015: 104). PYD ise "Arap Baharı" adı verilen ayaklanmaların Suriye'ye sıçramasına kadar bu ittifakların dışında kalmayı tercih etmiştir. Sonuç olarak, siyasi düşmanlıklar, liderlik çekişmeleri daha çok siyasi fragmansiyonlara yol açtı.

Suriye krizinde Kürt partilerin birleşme/uzlaşma diplomasisi iki ana çatı örgütü altında toplanabilir: Suriye Kürt Ulusal Konseyi (ENKS) ve Batı Kürdistan Demokratik Toplum Hareketi (TEV-DEM veya Meclisa Gel ya Rojavayê). ENKS çatısı bünyesinde bulunan siyasi partiler daha çok Mesud Barzani'nin güdümündeyken TEVDEM çatısında bulunan parti ve örgütler ise PYD kontrolünde siyasi faaliyetlerini yürütüyorlar. Aşağıdaki tabloda ENKS'ye üye partiler gösterilmektedir (Schmidinger, 2014).

\begin{tabular}{|l|l|l|l|}
\hline Party (Kürtçe) & Party (Türkçe) & Parti Başkanı & Yakınlık \\
\hline $\begin{array}{l}\text { Partiya Demokrat a } \\
\text { Kurdistan-Sûriyê }\end{array}$ & $\begin{array}{l}\text { Suriye Kürdistan } \\
\text { Demokrat Partisi }\end{array}$ & Suud Mele & $\begin{array}{l}\text { Barzani (KDP) ve Suriye } \\
\text { Ulusal Konseyi }\end{array}$ \\
\hline $\begin{array}{l}\text { Partiya Demokrat a Kurdî } \\
\text { li Sûriyê (el-Partî) }\end{array}$ & $\begin{array}{l}\text { Suriye Kürt Demokrat } \\
\text { Partisi (el-parti) }\end{array}$ & Nasreddin İbrahim & Barzani (KDP) \\
\hline $\begin{array}{l}\text { Partiya Welatparêz a } \\
\text { Demokrat a Kurdî li } \\
\text { Sûriyê }\end{array}$ & $\begin{array}{l}\text { Suriye Kürt Demokratik } \\
\text { Vatansever Partisi }\end{array}$ & Tahir Sifuk & $\begin{array}{l}1998 \text { yılında PDKS'den } \\
\text { ayrılma }\end{array}$ \\
\hline
\end{tabular}

${ }^{14}$ Uluslararası Kriz Grubu'nun (International Crisis Group) hazırladığı raporda Suriye Kürtleri Demokratik Birliğinin kuruluş yılı 1994 ve Suriye Kürt Demokratik Yurtsever Cephesi'nin kuruluş yılı 2000 olarak belirtilirken Schmidinger'in kitabında (Suriye Kürdistanı'nda Savaş ve Devrim: Rojavadan Sesler) ve Allsopp'un kitabında (The Kurds of Syria: Political Parties and Identities in the Middle East) 1992 ve 1996 yılları olarak geçmektedir. 


\begin{tabular}{|c|c|c|c|}
\hline $\begin{array}{l}\text { Partiya Demokrat a } \\
\text { Pêsverû ya Kurdî li } \\
\text { Sûriyê }\end{array}$ & $\begin{array}{l}\text { Suriye Kürt Demokratik } \\
\text { İlerici Partisi }\end{array}$ & Abdülhamit Hacı Derviş & Talabani (KYB) \\
\hline $\begin{array}{l}\text { Partiya Demokrat a Kurdî } \\
\text { Sûrî }\end{array}$ & $\begin{array}{l}\text { Suriye Kürt Demokrat } \\
\text { Partisi }\end{array}$ & $\begin{array}{l}\text { Abdurrahman Aluci - } \\
\text { Lazgin Mahmud Fahri }\end{array}$ & $\begin{array}{l}2013 \text { yılında el-parti'den } \\
\text { ayrılma }\end{array}$ \\
\hline $\begin{array}{l}\text { Partiya Wekhevî ya } \\
\text { Demokrat a Kurdî li } \\
\text { Sûriyê }\end{array}$ & $\begin{array}{l}\text { Kürt Demokrat Eşitlik } \\
\text { partisi }\end{array}$ & Aziz Davud & $\begin{array}{l}1992 \text { yllında PDKS'den } \\
\text { ayrılma }\end{array}$ \\
\hline $\begin{array}{l}\text { Partiya Azadî ya Kurdî li } \\
\text { Sûriyê }\end{array}$ & $\begin{array}{l}\text { Suriye Kürt Özgürlük } \\
\text { Partisi-Azadi }\end{array}$ & Mustafa Hidır Oso & $\begin{array}{l}2011 \text { yilında Azadi'den } \\
\text { ayrilma }\end{array}$ \\
\hline $\begin{array}{l}\text { Partiya Çep a Kurdî li } \\
\text { Sûriyê }\end{array}$ & Suriye Kürt Sol Partisi & $\begin{array}{l}\text { Muhammed Musa } \\
\text { Muhammed }\end{array}$ & PYD \\
\hline $\begin{array}{l}\text { Partiya Çepa Demokrat a } \\
\text { Kurdî li Sûriyê }\end{array}$ & $\begin{array}{l}\text { Suriye Kürt Sol Demokrat } \\
\text { Partisi }\end{array}$ & Muhammed Salih Gedo & $\begin{array}{l}2012 \text { yılında Suriye Kürt } \\
\text { Sol Parti'den ayrilma }\end{array}$ \\
\hline $\begin{array}{l}\text { Partiya Yekîtî ya } \\
\text { Demokrat a Kurdî li } \\
\text { Sûriyê }\end{array}$ & $\begin{array}{l}\text { Suriye Kürt Demokrat } \\
\text { Birlik Partisi }\end{array}$ & Muhittin Şeyh Ali & Talabani (KYB) \& PYD \\
\hline $\begin{array}{l}\text { Partiya Yekîtî ya Kurdî li } \\
\text { Sûriyê }\end{array}$ & Suriye Kürt Birlik Partisi & Ibrahim Biro & Barzani (KDP) \\
\hline $\begin{array}{l}\text { Partiya Demokrat a Kurdi } \\
\text { ya Suri }\end{array}$ & $\begin{array}{l}\text { Suriyeli Kürt Demokratik } \\
\text { Partisi }\end{array}$ & Cemal Şêyh Bakî & PYD / Suriye Rejimi \\
\hline Tevgera Reforma & Kürt Reform Hareketi & Faysal Yusuf & \\
\hline $\begin{array}{l}\text { Şepela Pesroje ya Kurdi li } \\
\text { Suriye }\end{array}$ & $\begin{array}{l}\text { Suriye Kürt Gelecek } \\
\text { Hareketi }\end{array}$ & Cemal Molla Mahmud & $\begin{array}{l}2011 \text { yllında Suriye Kürt } \\
\text { Gelecek Hareketi’den } \\
\text { ayrılma }\end{array}$ \\
\hline $\begin{array}{l}\text { Şepela Pesroje ya Kurdi li } \\
\text { Suriye }\end{array}$ & $\begin{array}{l}\text { Suriye Kürt Gelecek } \\
\text { Hareketi }\end{array}$ & Rezan Bahri Şeyhmus & $\begin{array}{l}2011 \text { yllında Suriye Kürt } \\
\text { Gelecek Hareketi'den } \\
\text { ayrılma }\end{array}$ \\
\hline
\end{tabular}

Tablo 1: ENKS Çatısı Altında Bulunan Siyasi Partiler ${ }^{15}$

Mesud Barzani aracılığıyla ENKS, Suriye Kürt partilerin kurduğu en kapsamlı çatı örgütü, Erbil şehrinde 26 Ekim 2011 tarihinde desteklenmiştir. Genelde rejime karşı Kürt partilerden oluşan konsey Barzani'den destek alarak Kürt haklarını korumak amacında ve Suriye devriminin bir parçası olarak kendini konumlandırmaktadırlar. ENKS kendini Suriye muhalefetinin bir parçası görerek rejimle diyalog içerisinde bulunmayı reddederken, PYD’ye karşı da mücadele içerisinde olmuştur. PYD'yi rejimle işbirliği ve gizli anlaşmalar yapmakla suçlamaktadır. Federalizm ve öz-yönetim gibi klasik modelleri reddeden PYD ise “demokratik özerklik" ve anayasal çerçevede Kürt haklarının tanınması talep etmektedir. PKK'ye yakınlığıyla bilinen TEV-DEM Suriye Kürt partilerinin oluşturduğu ittifak olan ENKS ile beraber 11 Haziran 2012'de Erbil'de gerçekleştirilen toplantıya katılmıştır. Erbil işbirliği anlaşması ${ }^{16}$ ile bütün Kürt partileri Kürt Yüksek Konseyi (Desteya Bilind a Kurd)

\footnotetext{
${ }^{15} 26$ Ekim 2011 yılında kurulan ve çeşitli aşamalardan sonra günümüzde bünyesinde sadece 7 parti bulunduran ENKS, KDP Lideri ve Irak Kürdistan Bölgesel Yönetimi Başkanı olan Mesud Barzani'ye yakınlığıyla biliniyor. ENKS'yi günümüzde aynı zamanda Suriye Kürt Birlik Partisi (Partiya Yekîtî ya Kurdî li Sûriyê) başkanı İbrahim Biro temsil etmektedir.

${ }^{16}$ Yedi maddelik Erbil mutabakatı ile Kürt Yüksek Konseyi kurulmuştur.

1. Birleşik bir siyasi amaç geliştirmek ve siyasi ve diplomatik çabaları koordine etmek için bir Ortak Yüksek Komite kurulacak. Bu siyasi amaç Suriye'de bir ulus ve etnik grup olarak Kürt halkının değişmez değerlerine dayanacak ve Şam'daki diktatörlüğün devrilmesi, demokratik, çoğulcu bir devletin inşası birçok etnik grubun birlikte yer aldığı yeni bir Suriye yaratılması için çalışacak. Yeni Suriye anayasasında orijinal halk olarak halkımızın varlığını tanıyarak halkımızın isteklerini karşılayacak. Kürt sorunu demokratik yollarla çözümlenecek.

2. Erbil Anlaşması'nın yerine getirilmesi için bir mekanizma oluşturulacak.

3. Tüm bölgelerde pratik işlerin yürütülmesini koordine etmek için bir Yüksek Örgütlenme Komitesi kurulacak.
} 
bünyesinde bir araya getirildi (http://www.kurdwatch.org/pdf/KurdWatch_D027_en_ar.pdf). Ancak PYD, ne rejime karşı Suriye Ulusal Koalisyona ne de Suriye Muhalif ve Devrimci Güçler Ulusal Koalisyonuna dâhil olmad1. ${ }^{17}$ Bu tutumu nedeniyle yoğun bir şekilde eleştirildi.

$\mathrm{Bu}$ arada birçok siyasi parti ise zamanla ENKS üyeliğinden ayrıldı ve/ya sadece isimleri sembolik olarak listede kaldı. 22 Ekim 2014'te iki ana çatı örgüt arasında Duhok'ta imzalanan bir başka anlaşma ise çok geçmeden uygulanmaya geçilmediği görülmüştür. Suriye'deki savaşın sona ermesi için Birleşmiş Milletler aracılığıyla İsviçre'nin Cenevre kentinde ve Kazakistan'ın Başkenti Astana'da yapılan Suriye görüşmelerine ENKS (Suriye muhalefeti içerisinde) davet edilirken PYD davet edilmediğinden görüşmelerin kararlarını tanımamıştır. Suriye'deki bir dizi diğer muhalefet ve Kürt politik grupla birlikte PYD, toplumsal sözleşme yoluyla demokratik özerklik adı altında Kürt bölgelerinin çoğunu kapsayan bir coğrafya ile kendini meşru kılma ve kabul ettirme çabasında.

Sonuç olarak, iki çatı altında faaliyet gösteren partilerin (Abdullah Öcalan'ın ideolojik yaklaşımını benimseyen partilerle Mesud Barzani’ye yakın partiler arasındaki uyuşmazlıklar ve nüfuz mücadelesi) sürekli birbirlerini suçlaması ve sert eleştirmesi işbirliği anlaşması/çabaları hükümsüz kılmıştır.

\section{3 İç ve Dış Etkiler \& İlişkiler}

Suriye'deki Kürt hareketinin ilişkileri ve etkileşimleri tarihi bu çalışmanın çerçevesinin epey dışına taşar. Ancak, Suriye'deki Kürt hareketi uzun süren mücadeleler sırasında hem kendi iç dinamikleri hem diğer Kürt hareketleri hem de bölgesel gelişmelerden etkilenmiştir (ORSAM 2012: 39). Bununla birlikte Suriye Kürt hareketi, Arap ayaklanmalarına kadar bölgesel Kürt dinamiğinden fazlaca etkilenirken bu tarih sonrası kendisi etkileyici olmaya başlamıştır (Merkez Strateji Enstitüsü (MSE), 2016: 13).

Orta Doğuda'da üç siyasi hareket Kürt siyaset sahnesinin çoğuna hakim oluyor: Türkiye'deki Kürdistan İşçi Partisi (PKK) ve Irak’taki Kürdistan Demokrat Partisi (KDP) ve Kürdistan Yurtsever Birliği (KYB). Bu partilerin üçününde Suriye'deki "kardeş partileri" bulunmaktadır. Daha önceki bölüm/lerde ayrıntılı belirtildiği gibi Suriye Kürt hareketi ve partilerin hizipleşmesi/bölünmesi Abdullah Öcalan'nın partisi PKK ve ideolojisini benimseyen partilerle Mesud Barzani'n KDP'sine bağlı olan partiler ve Celal Talabani'n KYB'sine yakın çizgide olan partiler arasındaki gerginlik ve güç mücadelesi ile açıklanabilir. Jordi Tejel'e göre, PDKS'den sonra ortaya çıkan Kürt partileri, genelde merkezi bir kişilik etrafinda örgütlenen ve Irak'taki ya da Türkiye'deki Kürt oluşumlarından biriyle bağlantılı içinde olmuşlardır (Tejel, 2015: 190). Suriye Kürt partilerin parçalanmasının nedenlerinden biri de budur.

4. Her bir bölgede pratik işlerin koordine edilmesi için alt komiteler kurulacak.

5. Tüm karşı propagandalar son bulacak.

6. Kürt bölgelerindeki tüm silahlı güçler kaldırılacak.

7. Ortak, silahsız koruma komiteleri kurulacak.

8. Toplumsal çatışmaları sona erdirmek için ortak arabulucu komiteler kurulacak. Bu komiteler bu gibi sorunlarda en yüksek sorumluluk sahibi otorite olacak.

${ }^{17}$ PYD kontrolündeki Kürtler, Suriye Ulusal Konsey ve Devrimci Güçler Ulusal Koalisyonu (SMDK) 'nu "Arap İslamcıların güçlü eğilimleri ile hala Arap milliyetçisi bir örgüt" olduğunu ileri sürmekte ve ülkenin etnik ve dini çoğulculuğu anlamında yetersiz olduğunu ima etmekteler. Ayrıca, Konsey'in Türk hükümeti etkisinde olduğunu ima etmekte ve güvenmemektedirler. 
Yürürlükte herhangi bir siyasi partiler yasası olmadığı için Suriye yönetiminin Kürt partilerine karşı izlediği politikası inişli-çıkışı bir seyir izledi; genelde Kürtlerin örgütlenmesi, seçime girmesi ve siyasi parti faaliyetleri yasaklanmıştır. Kürt partilerin parti bürosu açmasına ve tabela asması dışındaki faaliyetleri yasaklanmıştır (Bingöl, 2013: 60). Suriye Kürt partilerin bölünmesi daha çok Suriye rejiminin işine yaramış, dönemsel olarak Suriye gizli servisi veya istihbaratı (muhabarat) Kürt partileri üzerinde adeta demoklasin k1lıcı gibi her daim asılı kalmış ve örgütlenme ve mobilizasyonunu engelleyerek kontrol etmiştir. Yine partiler ayaklanmalar öncesi dönemde rejimin "kırmızı çizgilerini" dikkate alarak Suriye'de Kürtlerin olduğu ama Kürdistan'ın olmadığı görüşünü benimsemişlerdi (Schmidinger, 2015: 88-89). Partilerin bölünmesinde rejimle işbirliği de önemli rol oynamıştır. Harriet Allsopp rejimle işbirliği konusunda Kürt partilerini genel olarak 3 gruba ayırmıştır: Sağ (örneğin İlerici Parti rejimle resmi olmayan iyi ilişkiler içerisinde olmuş, Kamışlı olaylarında sonra rejime karşı protestolarda yer almamış), merkez (örneğin Demokratik Birlik Partisi gerektiğinde rejimle iyi ve kötü dialoğlar içerisinde olmuş ancak kırmızı çizgilere dikkat etmiştir) ve Sol (örneğin Birlik Partisi ve Gelecek Hareketi rejim tarafindan daima takip edilmiş ve faaliyetlerine izin verilmemiştir) (Allsopp, 2015: 117-118). Mart 2004 Kamışlı olaylarında ve sonrasında rejim sokak ve meydanları Kürt partilerinin yardımıyla nasıl sükûnet etmeye çalıştığını da göstermiştir.

Arap muhaleftiyle ilişkiler ise hep sınırlı bir seviyede kalmıştır. Demokratik Birlik Partisi, Yurtsever Partisi, Demokrat Eşitlik Partisi, Sol Parti, PDKS (el-parti), Uzlaşı Partisi Şam Beyannamesine destek verip temsil edilirken Kürtler ve hakları için yeterli bir zeminin oluşmadığını gerekçe göstererek Birlik Partisi (Yekiti), Özgürlük Partisi (Azadi) ve PYD bu oluşumdan uzak durmuştur. Öte yandan, Suriye Arap muhalefetinin ajandasında genelde milliyetçi söylemler yer alırken Kürt muhalefetinde ise daha çok kimlik, dil ve kültürel talepler ön planda bulunmuştur. Arap muhaliflerler dil, tarih ve kültür düzleminde Kürtlerin durumunu görmezden gelip adeta hasıraltı etmeyi tercih ettiler. Dolaysıyla, Kürt partilerin Kürt bölgelerindeki "Araplaştırma” siyaseti ve söyleminin dillendirilmesi Arap muhalefeti tarafından çoğu zaman bir tehlike olarak görülmüş. Bu durum, İsrail'in Filistin politikalarına benzetilmiştir (Allsopp, 2015: 100).

Gazateci-yazar Fehim Taştekin'e göre, muhalif partiler rejimin tepkisinden çekinmiştir. Çünkü Kürt sorunu Arap muhalefetin en temel çelişkisiydi; Arap eliti Suriye Kürtlerinin varlığı ve hakları konusunda duruşunu netleştirmekten uzaktı (2016: 115). Şam Beyannamesini destekleyen Kürtler Suriye'de demokratik reformları talep eden oluşumları desteklediler fakat uzun süreli bir proje görülmesi nedeniyle Kürt-Arap diyaloğu sınırlı bir seviyede kaldı (Allsopp, 2015: 114). Ayaklanmaların başlangıcından bu yana Arap milliyetçisi ve (1lıman) İslamcı kesimler ile Kürt partileri arasında işbirliği (genelde Barzani'in girişimiyle) başarıya ulaşmamış ve ulusal-uluslararası platformlarda Kürt toplumu yeterince temsiliyet edilememiştir. ${ }^{18}$ Müslüman Kardeşler'in Kürt partilerine yaklaşımı da "İslam veya ümmet kardeşliği”" sloganından öteye geçmemiştir.

Başkan Hafız Esad, komşu Irak ve Türkiye'den gelen Kürt partilere Suriye'de göreceli olarak özgürlükle çalışma imkânı verdi. Diğer bir deyişle, bu politika ile hem kendi bölgesel

\footnotetext{
${ }^{18}$ Suriye Ulusal Konseyi başkanlığına getirilen Kürt asıllı Abdulbasit Seyda bile Kürtleri konsey çatısı altında toplayamamıştır (Taştekin, 2016: 146)
}

International Journal of Kurdish Studies Vol.3/1 ( January 2017) 
heveslerinin gerçekleşmesi hem Kürt tehlikesini başkentten uzaklaştırması hem de 1970 ile 1990 yılları arasında Suriye rejimi kendi Kürt sorununu Irak ve Türkiye'ye taşımayı hedeflenmiştir (Tejel, 2015: 152). Öcalan'ın 1998'de tutuklanmasına kadar PKK, gerilla birlikleri için zaman zaman Suriye kontrolündeki Lübnan'da eğitim kampları düzenledi.

PKK ve Suriye rejimi arasındaki ilişki 1980'li yıllara dayanıyor. Suriye'deki Kürt siyasetine yön veren Abdullah Öcalan'ın ideolojik görüşleri özellikle daha sonra PYD çevrelerince geliştirilmiştir. Rejimle ilişkilerin göreceli olarak iyi olduğu 1980'li ve 1990'l1 yıllar PKK Suriye'deki Kürt hareketinin mücadelesini ve dikkatini daha çok Türkiye'ye yönlendirmiştir. Sonuç olarak, Suriye-Kürt partileri politik aktiviteler konusunda PKK ile yarışamamış hatta daha çok gölgesinde kalmıştır.

Suriye'deki ayaklanmalara kadar, KDP ve KYB'nin başkent Şam'da ve Kürtlerin yoğun olduğu Kamışlı'da parti ofisleri bulunmaktaydı. Hafız Esad'ın Iraklı Kürtlerle geliştirdiği siyasetin temel amacı hem rakip Baas partisinin gücünü zayıflatmak olmuştur hem de kendi Kürtlerinin ilgisini ülke dışına yöneltmek olmuştur (Taştekin, 2016: 70-71). Böylece Esad, komşu ülkelerle müzakerelerde baskı yapmak için kendisine bir araç sağladı ve Suriye Kürtlerinin Irak ve Türkiye'ye olan mücadele katılımını sağlamış fakat Suriye-Kürt sorunundan uzaklaştırmayı başarmıştır.

Dönemsel olarak, Suriye-Türkiye ilişkilerinde; PKK, Su, Hatay ve İsrail meselelerin parametreleri değişmiş olsa da Türk dış politikasının en çok tartışmalı dönemi, Arap Ayaklanmaları sonrasında gündem olmuştur. Suriye ayaklanmaları esnasında ve sonrasında PYD ile doğrudan bir anlaşma yapamayan AKP (Adalet ve Kalkınma Partisi) Hükümeti, bunun yerine, KBY lideri Mesud Barzani’yi devreye koymaya çalışmış, Barzani, 2012 yılında Erbil'de, Suriyedeki Kürt siyasi partilerini bir çatı altında toplamaya çalışmış fakat başarılı olamamıştır (Halhalli, 2015b). Ardından IŞ(ID)'in Kobanê saldırıları karşısında Ankara bir defa daha Suriyeli Kürtlere yönelik tutumunun tersine Barzani'yi tercih etmiş, Kobanê direnişi sırasında Peşmergelerin IŞ(ID) ile savaşmaları için Türkiye üzerinden Suriye geçişine yeşil ışık yakmıştır. Bu durum, 2004 Kamışlı olaylarından bu yana Suriye'deki Kürtlerin en kapsamlı ve stratejik eylemi olarak değerlendirilebilir.

$\mathrm{Bu}$ gelişme aynı zamanda Kürt tarihi açısından sınırlar arasında hapsedilen Kürt milliyetçiliğini de bölgeselleştirilmesinin yanısıra AKP Hükümetinin PYD’yi PKK ile eş görmesi (http://www.mfa.gov.tr/pkk.tr.mfa) ${ }^{19}$, Ankara, Kuzey Suriye'deki Kürt yapılanmasının Türkiye'nin güvenliğine tehdit oluşturduğunu, sınırın hemen güney tarafindaki devlet-dışı aktör olan Kürtlerin yüksek profilli siyasette etkin olduğunu ihmal etmesi, IŞ(ID)'in Kobanê kuşatmasında karşı hamlede bulunmaması, günümüzdeki Türk-Kürt kutuplaşmasında önemli derecede rol oynamaktadır (Halhalli, 2015b). Ayrıca, daha önce de belirtildiği gibi ABD liderliğindeki uluslararası koalisyonun korumasıyla Suriye'ye gönderilmek üzere binlerce Peşmergenin KBY'de eğitilmesi KDP'ye yakın Kürt partileri ile Suriye'deki PKK'ye yakın Kürt partileri arasında silahlı mücadele ve alan hâkimiyeti rekabetini daha da artıracaktır. Burdaki temel amaç PYD ve onun askeri kolu YPG'nin bölgedeki tekelini kendi lehine çevirmektir.

\footnotetext{
${ }^{19}$ AKP hükümeti hem PKK'yi hem de PYD’yi aynı örgütsel yapı, strateji, taktik, askeri yapı, propaganda araçları, mali kaynaklar ve eğitim kampları kullanmaları nedeniyle terör örgütleri olarak tanımlamaktadır. $P K K$; $A B$ ve ABD tarafından terör örgütü olarak kabul edilirken PYD/YPG öyle değerlendirilmemektedir.
} 
PYD öncülüğünde Esad rejimi ve Özgür Suriye Ordusu (ÖSO)'dan bağımsız, üçüncü bir yolda ilerleyen Kürtler ve bölgenin başına bela olmaya çalışan IŞ(ID) gibi güçlü bir örgüte karşı direnen kantonyonel bir Kürt bölgesi Türk hükümeti için tehdit oluşturmuştur. (Halhalli, 2015b). Öte yandan, Suriye-Kürt hareketi, Kobanê savaşı ve sonrasında radikal İslamcı örgütlerle mücadelede özellikle $A B D$ ve Avrupa ülkeleri ile olan ilişkilerini değiştirdi ve bunun yararlı bir müttefik olabileceğini kanıtladı. Özellikle ABD, IŞ(ID)ve El Nusra karşıtı koolisyon güçleri kapsamında 2014 Kobanê kuşatmasında PYD’yi siyasi YPG'yi askeri düzlemde destekleyip yardım etmeye başladı. Savaş uçaklarıyla IŞ(ID) mevkilerini bombalaması sırasında PYD'nin askeri kanadı YPG ile eşgüdüm içerisinde hareket etmektedir. Hâlihazırda ABD ile ülkenin kuzeyinde IŞ(ID)'e karşı savaşan YPG aynı zamanda çift yönlü bir strateji ile güneyde aynı rakipe karşı Rusya'dan da destek görmüştür.

Ayrıca, Suriye'deki Kürt hareketi Irak'ta 1990'lardan beri Kürt devleti inşasını yakın izlemiş ve tecrübe etmiştir. 2003 Amerikan'ın Irak işgali sonrası Irak Kürt milliyetçi hareketi Suriye Kürt hareketi tarafından izlenilse de Suriye Krizi sonrasında Irak KDP'si Suriye Kürtleri üzerinde PKK-PYD ikilisiyle güç mücadelesine girmiştir. Türkiye nazarındaysa PKK baş düşmandır ama KDP (Barzani) en iyi mütefiktir.

\section{SONUC}

Kendi iç ve diş dinamikleri olan ve bölgesel gelişmelerden etkilenen Suriye Kürt hareketi kuruluşundan bu yana, kültürel, ulusal ve insan hakları için mücadele ve siyasi baskılar gibi konulara yoğunlaşmıştır. Aynı zamanda, rejimin Kürtlere yönelik politikasını değiştirmeye çalışarak kimlik ve kültürel faaliyetleri ve uygulamaları için yasal bir platform oluşturmaya çalışmışlardır. Bir başka deyişle, Suriye'nin Kürt bölgelerine uygulanan Araplaştırma politikalarının tersine çevrilmesi, Suriye politik sisteminin demokratikleşmesi, insan haklarına saygı ve Kürt-Arap ilişkilerinin gelişmesi talep edilmektedir. Bugüne kadar yasallaşmayan ve resmi faaliyetlerde bulunmaları yasaklanan Kürt siyasi partileri Suriye'de bağımsız bir Kürt devleti/Kürdistanı talep etmediler; daha çok Suriye (Batı) Kürdistanı olarak adlandırılan Rojava'da demokratik özerklik ve/ya federalizm talep etmektedirler. Barışçıl çözüm arayışı, seküler yapı ve anayasal himaye, ayrımcı, ırkçı ve şovenist uygulamaları kaldırma ve 1962'de vatandaşlıktan çıkarılanların vatandaşlıklarının verilmesi ve Baas rejimi döneminde Araplaştırılan (Arap Kemeri) Kürt bölgelerin geri verilmesi bu taleplerin arasında. Suriye'deki Kürt partilerin neredeyse hepsi bölgesel egemen aktörlerin (özellikle Suriyeli İslamcı muhalifler, Irak, İran ve Türkiye siyasetindeki) radikal dini unsurlarından kendilerini uzak/ayrı tutmayı amaçlayan bir strateji uygulamaktadır. Kürt liderler, bu ayrımın Kürtlere uluslararası meşruiyet ve destek kazandıracağına inanmaktadırlar.

1957'de kurulan PDKS'den beri pek çok bölünme ortaya çıkmıştır. Bu bölünmeler ideolojik (sağc1-solcu), yeni ve çekici unsur teşkil etmekten daha çok biçimsel ve kişisel çıkar ve iç ve dış faktörler ile açıklanabilir. Hiçbir Kürt partisi -Suriye'deki Kürt hareketi, Irak'taki ve Türkiye'deki Kürt hareketinden farklı olarak- Kürt nüfusun bulunduğu bölgelerde silahlı mücadeleyi talep etmemiş ve yaymamışdır.

Öte yandan, Suriye'deki Kürt partilerinin iç örgütsel yapısı demokrasiye olan bağlılığıyla açıkça çelişiyor. Çok sayıda bölünme, Suriye Kürt sorunu ve ulusaşırı tabiatı nedeniyle KDP-PKK bloklar arası iktidar mücadelesi haline dönüşmüş ve dolayısıyla 
partilerin yapıları zayıfla(tıl)mıştır. Kürtlerin bölgesel siyasette bir güç olarak uzun vadeli başarısı, çeşitli Kürt siyasi hareketleri (çatı örgütlerinin) arasındaki işbirliği ilişkileri kurma becerilerine bağlı olacaktır. Suriye'deki Kürt siyaseti, PYD ile ENKS arasındaki derin çatlaklar ve rekabetlerle şekillenirken, işbirliği yapma ihtiyacı ise bu beklentileri kısmen de olsa yerine getirecektir. Ayrıca, başta ABD olmak üzere Türkiye, KBY ve Rusya Suriye'deki Kürt hareketinin geleceğinde önemli rol oynacaktır. KBY, Türkiye ile olan ilişkisini korumak için dikkatli davranırken Suriye'nin Kürt bölgelerindeki gelişmelerden etkilenmekte ve dolayısıyla, KBY-Türkiye ilişkisi KBY'nin PYD ile işbirliği kabiliyeti üzerinde önemli k1sitlamalar getirmektedir.

\section{KAYNAKÇA}

Allsopp, H. (2015) The Kurds of Syria: Political Parties and Identities in the Middle East, IB Tauris: London-New York

Arslan, S. (2016) “Rojava Kronoloji I”, Toplum ve Kuram, Say1: 11, Bahar 2016

Bengio, O. (2014) Kurdish Awakening: Nation Building in a Fragmented Homeland, University of Texas Press: Austin

Bingöl, N. (2013) Suriye'nin Kimliksizleri Kürtler, Do yayınları: İstanbul

Bolme, S. M. (2015), "Hoybun Örgütü: Kürt Milliyetçiliğinde Yeni bir Evre [Hoybun Organization: A new era in Kurdish Nationalism]", International Journal of Kurdish Studies, 1 (2), S. 22-42.

Bulut, F. (2015a) Tarih Boyunca Kürtlerde Diplomasi 1. Cilt, Evrensel Basım Yayın: İstanbul

Bulut, F. (2015b) Tarih Boyunca Kürtlerde Diplomasi 2. Cilt, Evrensel Basım Yayın: İstanbul, S. 100.

Halhalli, B. (2015a) "Turkish Policy towards the Kurds in Syria", Conflicts, Context \& Realities in the Middle East-IDEAZ Journal, Sayı: 13

Halhallı, B. (2015b), “Türkiye'nin Rojava Çıkmazı”, Türkiye Politika ve Araştırma Merkezi (Research Turkey), Cilt IV, Say1 3, S. 93-99, Londra: Research Turkey

Human Rights Watch (2009), Group denial: Repression of Kurdish political and cultural rights in Syria. (Toplu inkar: Suriye'deki Kürtlerin siyasi ve kültürel haklarının baskılanması.) New York, NY: Human Rights Watch

Gunter, M. (2011), The Kurds Ascending: The Evolving Solution to the Problem in Turkey and Iraq, Palgrave Macmillan: New York

International Crisis Group (2013) Syria's Kurds: A Struggle within a Struggle. Middle East Report no. 136. Brussels: ICG

Kurdswatch (2011), Who is the Syrian-Kurdish Opposition? The Development of Kurdish Parties, 1956-2011, Report 8, http://kurdwatch.org/pdf/kurdwatch_parteien_en.pdf 
Kutschera, C. (2013) Kürt Ulusal Hareketi, Avesta Kitap: İstanbul

Merkez Strateji Enstitüsü (MSE) (2016)“Suriye'deki Kürt Hareketi: Suriye'de

PYD/YPG'nin PKK ve Bölgesel Kürt Dinamiği ile İlişkisi ve Türkiye'ye Etkileri”, Rapor No: 14

Minorsyk, V. \& Bois, T. (2008) Kürt Milliyetçiği, Örgün Yayınevi:İstanbul

ORSAM (2012) “Suriye'deki Kürt Hareketleri (Kurdish Movements in Syria)", Rapor No:127,http://www.orsam.org.tr/eski/tr/trUploads/Yazilar/Dosyalar/201286_127\%20yenir aporson.pdf

Schmidinger, T. (2015) Suriye Kürdistanı'nda Savaş ve Devrim: Rojavadan Sesler, Analizler, Yordam Kitap: İstanbul

Schmidinger, T. (2014) "Syrian-Kurdistan and its Political Actors", Research Briefing, (Handout) at the Conference: The Syrian Conflict and the Promotion of Reconciliation and its Implications for International Security (Vienna, February 6-7, 2014)

Taştekin, F. (2016) Rojava Kürtlerin Zamanı, İletişim Yayınları: İstanbul.

Tejel, J. (2015) Suriye Kürtleri: Tarih, Siyaset ve Toplum, İntifada Yayınları: İstanbul

Tejel, J. (2009) Syria's Kurds: History, Politics and Society, Routledge: New York

Türkiye Cumhuriyeti Dışişleri Bakanlığı'nın resmi websitesi:

http://www.mfa.gov.tr/pkk.tr.mfa

“Suriye Kürdistan Demokrat Partisi Başkanını Seçti”, Anadolu Ajansı, 09.04.2014. http://aa.com.tr/tr/dunya/suriye-kurdistan-demokrat-partisi-baskanini-secti/168560

"Syrian Peshmerga to Return Home After Training in Iraq", Anadolu Ajansl (Anadolu Agency), 24.01.2017. http://aa.com.tr/en/middle-east/syrian-peshmerga-to-return-homeafter-training-in-iraq/734111

http://www.kurdwatch.org/pdf/KurdWatch_D027_en_ar.pdf 